\title{
GEOLOGY, GEOPHYSICS, AND GEODYNAMICS OF EXTENSIVE KCR VOLCANISM DURING PROTEROZOIC TIME IN INDIA
}

\author{
Saurabh K. Verma ${ }^{1}$ \\ ${ }^{1}$ National Geophysical Research Institute, Hyderabad, India
}

\section{GEOLOGICAL SETTING}

India has the largest repository of Proterozoic $(\sim 1.1$ Ga) kimberlite clan rocks (KCR's) in the world. The term KCR is used in the present study because of the uncertain classification of a number of kimberlites/lamproites in India (Madhavan, 2002; Ravi
Shanker, et. al, 2001; Scott Smith, 1989). These KCR's are confined to four major Indian cratons and adjoining Proterozoic mobile belts. Figure 1 shows the distribution of various cratons, mobile belts and KCR's (shown as kimberlites and lamproites based on their preliminary geochemical affinities). So far about 100 KCR's have been located in these provinces.

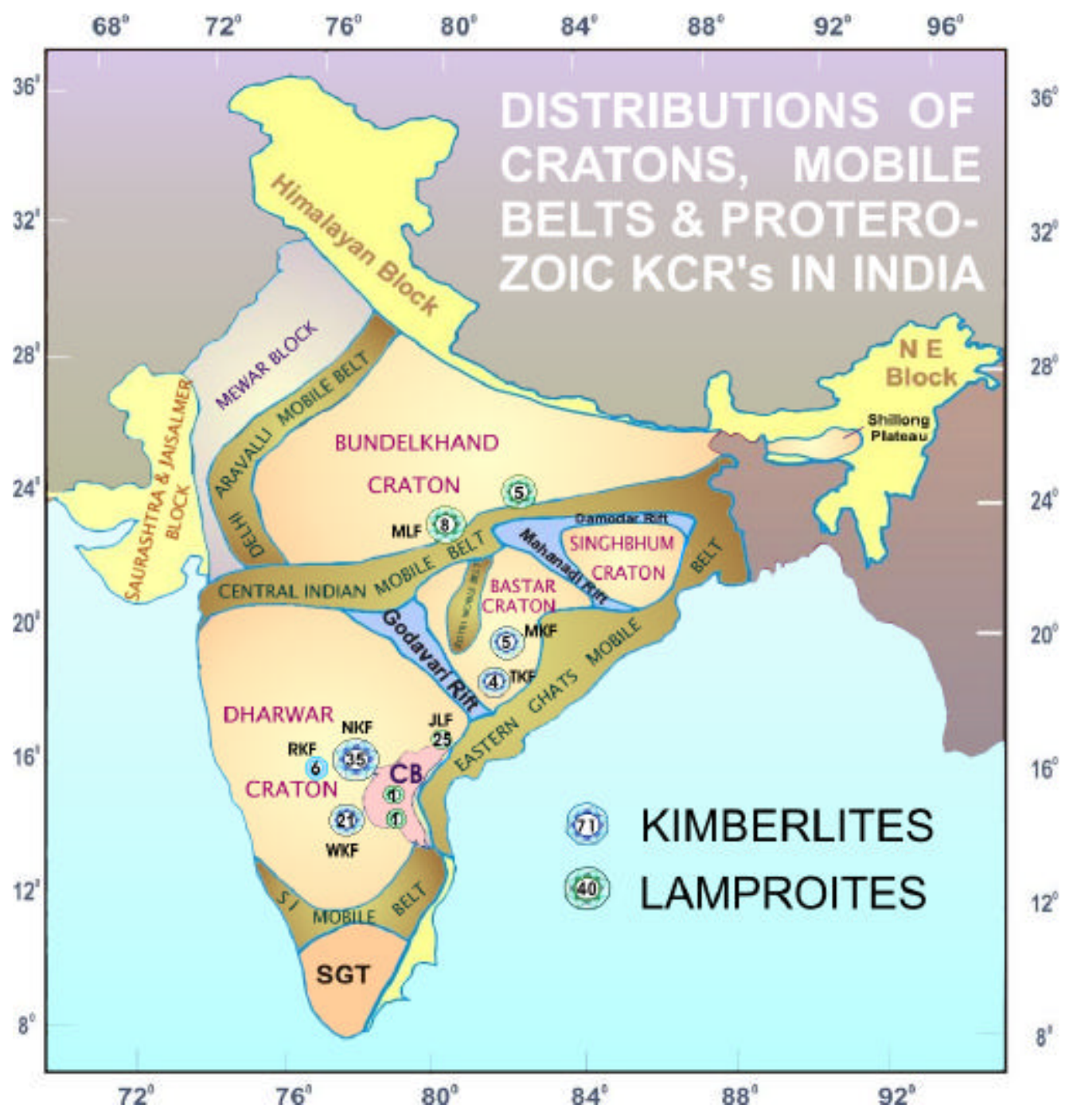

Figure 1: Distribution of various cratons, Proterozoic mobile belts, and KCR's in India. 
The eastern part of Dharwar Craton contains about 80 of these in the vicinity of intracratonic Cuddapah Basin (CB) from where world famous diamonds like Koh-iNoor, Nizam, Orloff, Great Moghul, Pitt (Regent), Darya-i-Noor, etc. were won in the past. Major well established kimberlite clusters occur along the western margin of $\mathrm{CB}$ with the Wajrakarur Kimberlite Field (WKF) in south and the Narayanpet Kimberlite Field (NKF) in north. Further westward occurrences of kimberlites are established by the discovery of Raichur Kimberlite Field (RKF) in recent years. Within the Nallamalai Fold Belt along the eastern margin of CB the Chelima Lamproite Field (CLF), comprising a few well known dykes, is well established. Along the northeastern margin of CB a new lamproite field, called Jagayyapeta Lamproite Field (JLF) with more than 2 dozen dykes, is established recently based on geological investigations during the last couple of years. In Bastar Craton two kimberlite fields, the Mainpur Kimberlite Field (MKF) with 5 pipes and the Tokapal Kimberlite Field (TKF) with 4 pipes were discovered in 1990's. Bundelkand Craton comprises at least 2 distinct clusters of KCR's (lamproites?) located along the margin of Central Indian Mobile Belt (CIMB). The first cluster at Majhgawan, designated as Majhgawan Lamproite Field (MLF) by the Geological Survey of India (Satyanarayana, 2002) comprises 8 known bodies including India's only diamond producing mine at Panna (Majhgawan Pipe). The other cluster, comprising 5 bodies, is located in Mirzapur District, UP. Not much work has been reported on these bodies .

\section{GEOPHYSICAL SignATURES OF FAVOURABLE LITHOSPHERIC CONDITIONS}

The depths at which carbon can remain stable in the form of diamond are around 150-200 km where the temperature range of $900-1400{ }^{0} \mathrm{C}$ and pressure conditions of 50-60 kbar prevails. A thick and cool lithosphere is necessary for the formation, stability and preservation of diamonds. Thus, over a favorable lithosphere, the surface heat flow values may not exceed 40-45 $\mathrm{m} \mathrm{Wm}^{-2}$. Such a lithosphere also possesses typical geophysical characteristics that could be identified on a regional scale of the order of $400 \mathrm{~km}$ or more. Other important geophysical characteristics include the regional gravity, magnetic and seismic responses of the lithosphere. A careful and integrated study of these responses can help in recognizing the mantle-root-friendly or mantle-root-destructive conditions as well as the diamondiferous nature of the kimberlites (Bank et al., 1998).

\section{Geophysical Characteristics of the Indian Lithosphere}

Geophysical characteristics of the lithosphere under Indian peninsula are described in detail by Verma (2000) to identify regions suitable for the occurrence of primary deposits of diamond. First of all the heat flow data is analyzed (Figure 2) to identify cratonic areas with low heat flow values. Available heat flow data

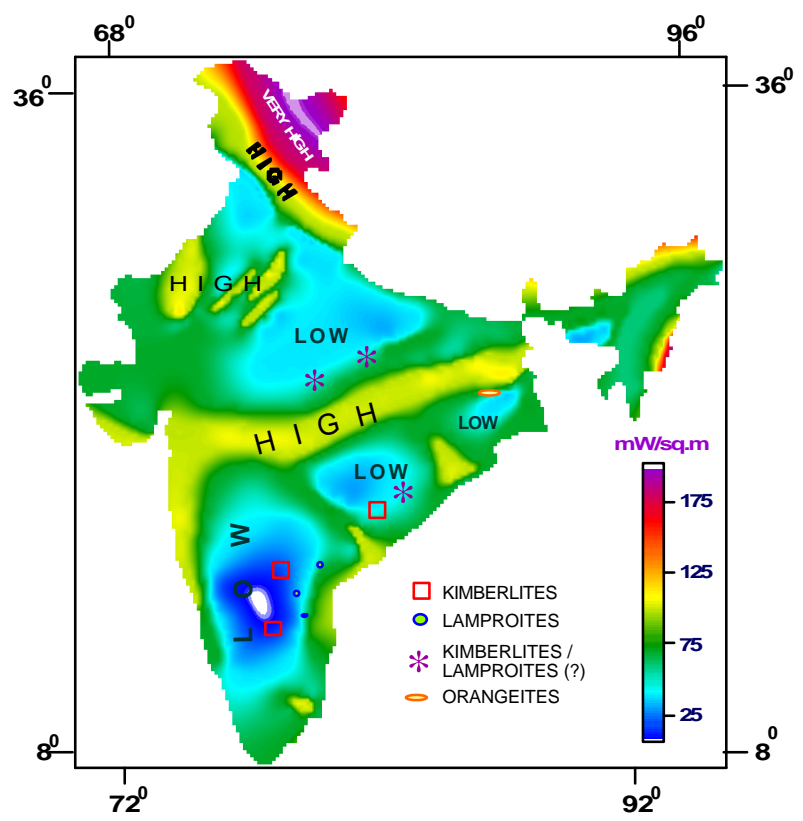

Figure 2: Heat flow map of India along with the occurrences of diamond source rocks.

over India is rather scanty and unevenly distributed. However, based on the studies by Gupta (1995) and Roy et al. (1996) we can conclude that: (1) The Archean Western Dharwar Craton is characterized by lowest heat flow $\left(31 \pm 4.1\right.$ (s.d.) $\left.\mathrm{mWm}^{-2}\right)$, (2) Archean and Archean-Early Proterozoic cratons have values around $39 \pm 4.0 \mathrm{mWm}^{-2}$, and (3) the Proterozoic mobile belts yield higher heat flow values of the order of $62 \pm$ $10.8 \mathrm{mWm}^{-2}$. To depict the occurrences of known kimberlites and lamproites over various heat flow regimes, the heat flow contour map by Ravi Shanker (1988) is used in Fig. 2. However, this heat flow map should be considered only for first order qualitative purposes. Despite the scanty data it is possible to see in Fig. 2 that all the known clusters of kimberlites occur on cratons characterized by very low heat flow. Lamproites, on the other hand, occur on or close to mobile belts with higher heat flow values.

Subsequently, the Bouguer gravity data is studied to qualitatively assess the crustal and lithospheric 
structures below various cratons and mobile belts. At present the magnetic anomaly map of India is not available. Therefore, MAGSAT anomalies are considered to study the structure of magnetic crust derived on the basis of Curie point isotherm. To get an idea about the mantle roots and lithospheric structures, the available results from limited seismic tomography experiments carried out in peninsular India are utilized (Rai et. al, 2003, Srinagesh and Rai, 1996, Rai et. al, 1992). Seismic tomography experiments in India started in the beginning of this decade. Preliminary results of the P-wave teleseismic experiment conducted over the south Indian shield are shown in Figures 3a and $3 \mathrm{~b}$ for depth ranges $50-175 \mathrm{~km}$ and $175-350 \mathrm{~km}$, respectively. Occurrences of KCR's in the Dharwar and Bastar Cratons are also shown in these figures. It may be seen that at shallower depths, the kimberlitic clusters of WKF as well as the NKF lie close to high velocity region indicating a relatively thicker and cooler lithosphere. At deeper levels (Fig. 3b) it can be seen that the WKF is associated with high velocities indicating the presence of a relatively thicker and cooler lithosphere compared to NKF. On the basis of these preliminary results, it could be surmised that possibly the lithosphere-asthenosphere structures below the two fields are qualitatively different. Murthy and Dayal (1998) conclude that 'Mahaboob Nagar kimberlites (same as NKF) represent lower pressure and higher degree of partial melt than Wajrakarur kimberlites (WKF)'. This is also supported by the seismic tomography results.

Spatial distributions of the regional and deep seated structural features are then studied to identify areas that could be promising from the view point of the occurrence of source rocks for diamonds.

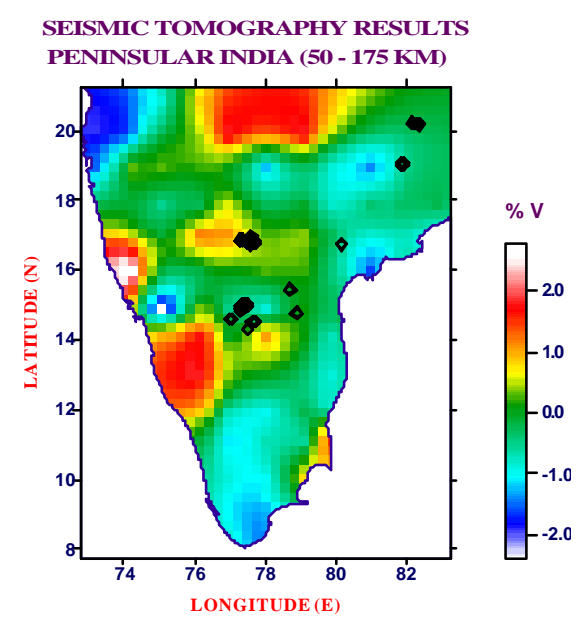

Fig. 3a: Seismic tomography results for 50-175 km depths (after Rai et al., 1992)

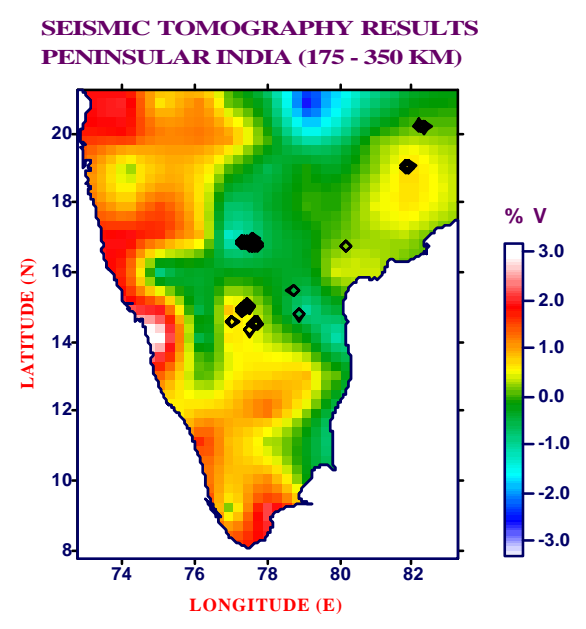

Fig. 3b: Seismic tomography results for 175-350 km depths (after Rai et al., 1992)

\section{GEODYNAMICAL ASPECTS}

The central Indian region, comprising Son-NarmadaTapti lineament and the Central Indian Mobile Belt (CIMB), represents a major geological setting that holds key to the evolution of Indian sub-continent. The CIMB separates the Bundelkhand cratonic block in the north from the southerly cratonic blocks of Dharwar and Bastar. It possibly represents the suturing of various cratonic blocks resulting from continentcontinent collision tectonics during the Mesoproterozoic time.

Modeling of egional Bouguer gravity data over the central Indian tectonic region incorporating the constrains provided by results from deep seismic sounding and magneto-telluric studies reveal the presence of regional underplating all along the central Indian tectonic zone (Verma and Singh, 2001). High heat flow values and seismic tomography results further suggest the presence of a thin lithosphere which has interesting implications on the occurrence of diamondiferous kimberlite clan rocks in the region.

It is now well established by geochronological studies that the KCR volcanism was confined to a narrow window in time. Spatially widespread and coeval nature of these KCR's suggests a major thermo-magmatic activity of regional nature around $1.1 \mathrm{Ga}$. In order to understand their origin, it is imperative to study the paleo-geographic distribution of various proto-cratonic blocks that evolved into present day Bundelkhand, Dharwar, Bastar, and Singhbhum Cratons. Based on 


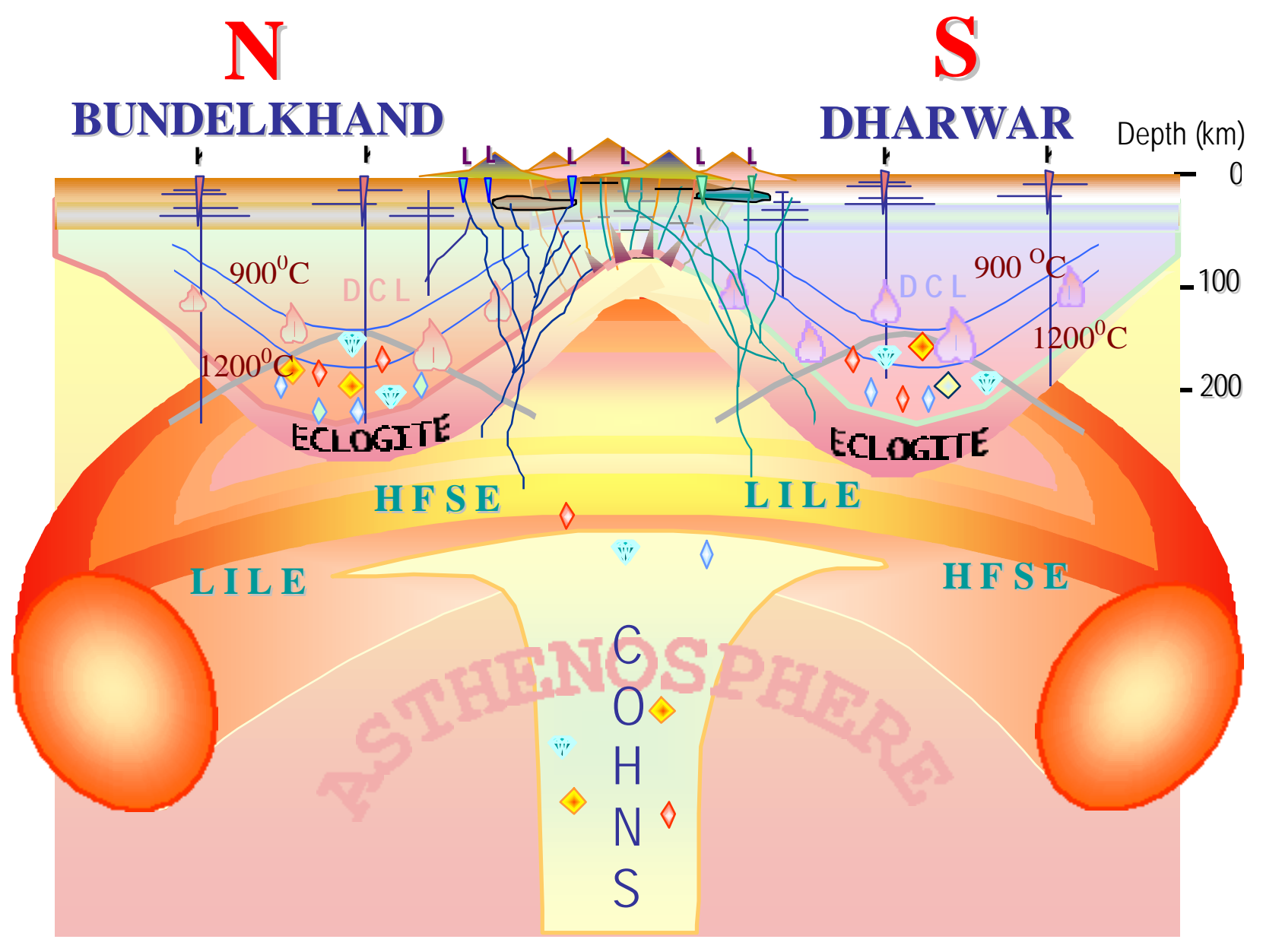

Figure 4 : Interaction of superplume with Bundelkhand and Dharwar Cratons around $1.1 \mathrm{Ga}$ causing widespread KCR volcanism.

available geochronological and paleomagnetic data, a reconstruction in time reveals that most of the protocratonic blocks were formed proximally around Paleoarchean time. Suturing of northern proto-cratonic (Bundelkhand) block with the southern (Dharwar, Bastar, and Singhbhum) blocks was completed by Late Archean/Paleoproterozoic time. Lithosphere(s) below these blocks grew steadily with time and by Mesoproterozoic time thickness of lithosphere below various cratonic blocks was sufficient to have P-T conditions suitable for the preservation of diamonds (Figure 4).

Around $1.1 \mathrm{Ga}$, various Indian cratons; as well those from west Australia, central and southeast Africa, and Sao Francisco Craton in South America; were contiguous and formed part of the Rodinia supercontinent. It is interesting to note that most of the Proterozoic kimberlites in the world are located in these regions and show an age around $1.1 \mathrm{Ga}$. Thus a common causative factor like a superplume seems to be able to explain the origin of such a large number of
Proterozoic kimberlites in regions that are presently separated by thousands of miles (Haggerty, 1999). The proposed model also explains some of the deeper characteristics of the sub-cratonic lithosphere in central India deciphered by seismic sounding and tomography, heat flow, gravity, and MAGSAT studies.

\section{REFERENCES}

Bank C.G., Bostock, M. G., Ellis, N.M., Hajnal, Z., VanDeca, J.C., 1998. Lithospheric mantle structure beneath the TransHudson orogen and the origin of diamondiferous kimberlites. Jour. of Geophys. Res., 103 (5), 10,103-10114.

Gupta, M.L., 1995. Thermal regime of the Indian shield, In: (Eds. Gupta, M.L. and Makoto, Y.), Terrestrial Heat Flow and Geothermal Energy in Asia. Oxford and IBH Publishing Co. Pvt. Ltd., India, pp 63-81.

Haggerty, Stephen E., 1999. Diamond formation and kimberlite-clan magmatism in cratonic settings. In: Yingwei Fei, Constance M. Bertka, and Bjorn O. Mysen (Eds.), Mantle Petrology: Field Observations and High Pressure 
Experimentation: A Tribute to Francis R. (Joe) Boyd. The Geochemical Society, Spl. Publication No. 6, pp. 105-123.

Madhavan, V., 2002. The present status of lamproites from the central and eastern Indian States: An identity crisis in the offing? Int. Conf. on: 'Diamonds and Gemstones, Raipur, Chhattisgarh, India, Feb. 9-15, 2002, 14-16.

Murthy, D.S.N. and Dayal, A.M., 1998. Geology and geochemistry of kimberlites of Andhra Pradesh, 24th Annual AEG Convention and Seminar on Exp loration Geophysics, Oct. 28-31, 1998, Nagpur, India.

Rai, S.S., Ramesh, D.S., Srinagesh, D., Suryaprakasam, K., Mohan, G., Rajagopal Sarma, P.V.S.S., and Satyanarayana, Y., 1992. Seismic tomography of the south Indian shield, Current Science, Spl. Issue on: 'Seismology in India - An overview, 62, Nos. 1\&2, pp 213-226.

Rai, S.S., Keith Priestley, Suryaprakasam, K., Srinagesh, D., Gaur, V.K., and Du, Z., 2003. Crustal shear velocity structure of the south Indian shield, Jour. of Geophys. Res., 108, No. B2, 2088.

Ravi Shanker, 1988. Heat flow map of India and discussions on it's geological and economic significance, Indian Minerals, Vol. 42, 2, pp 89-110.

Ravi Shanker, Nag, S., Ganguly, A., Absar, A., Rawat, B.P., and Singh, G.S., 2001. Are Majhgawan-Hinota pipe rocks truly Group I kimberlite? Proc. Ind. Acad. Sci. (Earth and Planet. Sci.) 110, 63-76.

Roy, S., Sundar, A., and Rao, R.U.M., 1996. Heat flow studies over the Deccan Volcanic Province, Gondawana Geological Magazine, Spl. Vol. 2, pp 475-482.

Satyanarayana, S.V., 2002. Diamond provinces of India: An overview, Int. Conf. on: 'Diamonds and Gemstones, Raipur, Chhattisgarh, India, Feb. 9-15, 2002, 44-45.

Scott Smith, B.H., 1989. Lamproites and kimberlites in India. Neus Jarbuch Miner. Abh 161,193-225.

Srinagesh, D. and Rai, S.S., 1996. Teleseismic tomographic evidence for contrasting crust and upper mantles in south Indian Archaean terrains, Phys. Earth and Planet. Int., 97, pp 27-41.
Verma, Saurabh K., 2000. Geological and geophysical fabric of Indian cratons in context of diamond exploration. In: Saurabh K. verma (Ed.), Status, Complexities and Challenges of Diamond Exploration in India. Proc. USEFI Workshop, Raipur, India, pp. 9-20.

Verma, S.K. and Singh, K.P., 2001. Regional underplating in central India: Supportive geophysical evidences, IGU $38^{\text {th }}$ Annual Convention and Meeting, Dec. 18-20, Visakhapatnam, India.

Contact: Saurabh K. Verma, National Geophysical Research Institute, Uppal Road, Hyderabad 500 007, India.

E-mail: skvngri@hotmail.com 